IZA DP No. 9647

Is Shale Development Drilling Holes in the Human Capital Pipeline?

Dan S. Rickman

Hongbo Wang

John V. Winters

January 2016 


\title{
Is Shale Development Drilling Holes in the Human Capital Pipeline?
}

\author{
Dan S. Rickman \\ Oklahoma State University
}

Hongbo Wang

Oklahoma State University

John V. Winters

Oklahoma State University

and IZA

\author{
Discussion Paper No. 9647 \\ January 2016
}

IZA

P.O. Box 7240

53072 Bonn

Germany

Phone: +49-228-3894-0

Fax: +49-228-3894-180

E-mail: iza@iza.org

Any opinions expressed here are those of the author(s) and not those of IZA. Research published in this series may include views on policy, but the institute itself takes no institutional policy positions. The IZA research network is committed to the IZA Guiding Principles of Research Integrity.

The Institute for the Study of Labor (IZA) in Bonn is a local and virtual international research center and a place of communication between science, politics and business. IZA is an independent nonprofit organization supported by Deutsche Post Foundation. The center is associated with the University of Bonn and offers a stimulating research environment through its international network, workshops and conferences, data service, project support, research visits and doctoral program. IZA engages in (i) original and internationally competitive research in all fields of labor economics, (ii) development of policy concepts, and (iii) dissemination of research results and concepts to the interested public.

IZA Discussion Papers often represent preliminary work and are circulated to encourage discussion. Citation of such a paper should account for its provisional character. A revised version may be available directly from the author. 


\section{ABSTRACT}

\section{Is Shale Development Drilling Holes in the Human Capital Pipeline?}

Using the Synthetic Control Method (SCM) and a novel method for measuring changes in educational attainment we examine the link between educational attainment and shale oil and gas extraction for the states of Montana, North Dakota, and West Virginia. The three states examined are economically-small, relatively more rural, and have high levels of shale oil and gas reserves. They also are varied in that West Virginia is intensive in shale gas extraction, while the other two are intensive in shale oil extraction. We find significant reductions in high school and college attainment among all three states' initial residents because of the shale booms.

JEL Classification: Q4, R1, R2

Keywords: shale development, synthetic control method, educational attainment

Corresponding author:

John V. Winters

Oklahoma State University

331 Business Building

Stillwater, OK 74078-4011

USA

E-mail: jvwinte@okstate.edu 


\section{Introduction}

The intensive development of U.S. shale oil and gas resources through hydraulic fracturing (fracking) that began in earnest after 2005 dramatically increased employment and income in many state and local economies (Weber, 2012; Brown, 2014; Weinstein, 2014; Munasib and Rickman, 2015). Development of shale oil and gas resources in the lower 48 states largely drove the 35 percent increase in dry natural gas and the nearly 44 percent increase in oil production from 2005-2013 in the nation (U.S. Energy Information Administration, 2015). Despite concerns with the extraction of resources on U.S. educational attainment in the 'resource curse' literature (Black et al., 2005; Papyrakis and Gerlagh, 2007; Michaels, 2011; Walker, 2013; Haggerty et al., 2014; Morissette et al., 2015), little attention has been given to the effects of shale oil and gas development on educational attainment.

With projections of significant long-run increases in shale oil and gas production in the U.S. (U.S. Energy Information Administration, 2015), adverse effects on human capital formation in areas rich with shale oil and gas could harm their long-run economic growth and development. Economic opportunities provided by the shale boom to younger, lesser educated workers, may cause them to drop out of high school or forego attending college; increased availability of higher paying shale oil and gas jobs increases the opportunity costs of education. Yet, the booms and busts inherent in the energy industry may cause the decision to forego education to be costly to the individual and overall economy in the long run.

In the only published study on the effects of fracking on educational attainment in the U.S., Weber (2014) examines 362 nonmetropolitan counties of Arkansas, Louisiana, Oklahoma, and Texas. Census 2000 provided the beginning-period estimates of educational attainment, while the average over 2007-2011 from the American Community Survey provided the ending-

period educational attainment estimates. Weber estimated that increased shale gas production in 
these counties reduced the number of high school dropouts in the counties, increased the number of high school graduates by more than their population proportions, and increased the number of people with some college or graduated college in line with their corresponding population proportions. Weber did not find any spillover effects across counties. The study did not address the effects of shale oil production.

In a working paper, Cascio and Narayan (2015) examine the effects of fracking on high school dropout rates on local labor markets across the lower 48 states of the U.S. Local labor markets are defined as commuting zones, while data for the period of analysis come from the 2000 Census and the 2005-2013 American Community Surveys. They focus on high school dropout rates for 15- to 18-year olds to remove the potential effects of migration of educational cohorts on educational attainment in the local area. High school dropouts of male teens is found to increase in areas with higher per capita shale oil and gas reserves relative to areas with lower reserves in the same state; the high school dropout rates of females were not found to have been affected, consistent with the belief that shale oil and gas extraction primarily affected the demand for low-educated males. They did not examine college enrollment and the focus on high school dropouts precludes estimating longer term effects on educational attainment.

In this study we employ novel methods of measuring educational attainment and constructing counterfactuals to further examine the link between fracking and high school and college attainment of the affected area. First, we use educational attainment of the native born population. This removes the effect of in-migration on area educational attainment (Michaels, 2011; Weber, 2014). Focusing on educational attainment accounts for the possibility that shortterm enrollment may be affected but not longer term accumulation of human capital (Emery et al., 2012). Fracking booms may increase high school dropouts in the short-run but the dropouts 
may later obain GEDs, while college enrollment may simply be delayed. Second, we use the Synthetic Control Method (SCM) (Abadie and Gardeazabal, 2003; Abadie et al., 2010) to establish the counterfactual. The counterfactual is constructed as a weighted-average of comparison areas based on demonstrated likeness. The advantage is that no single match with all the comparable characteristics to the shale oil and gas area is required and it controls for both pre- and post-treatment trends unrelated to shale and oil gas development. We conduct placebo tests for statistical inference about the estimated effects of fracking on high school and college attainment.

The next section presents the empirical approach, including discussion of the SCM and the selection of the states of Montana, North Dakota and West Virginia for analysis-three states with significant shale reserves-for the analysis. Section 3 presents the SCM results. We find that fracking booms reduced both high school and college attainment in Montana, North Dakota and West Virginia. The reduction in educational attainment ranged from approximately 3 to 6 percentage points. Only in one case (West Virginia), was the estimated treatment not larger than those estimated in placebo analysis, in which only one placebo estimate exceeded the estimated treatment effect. The results are shown to be robust to alternative synthetic control specifications. Section 4 summarizes the study and discusses the key distinguishing findings.

\section{Empirical Approach}

We examine the states of Montana, North Dakota and West Virginia. Among the states listed by Cascio and Narayan (2015) as possessing clusters of high oil and gas reserves based on btu contents, these three are small and had the largest nonmetropolitan shares of total employment in the states in 2005, which makes it more likely that the effects of the shale boom 
can be detected (Weinstein and Partridge, 2011; Munasib and Rickman, 2015). ${ }^{1}$ Montana and North Dakota lie above the Bakken shale oil play, while West Virginia lies above the Marcellus shale natural gas play. Munasib and Rickman (2015) found larger employment multiplier effects from the fracking boom in North Dakota nonmetropolitan counties extracting shale oil than in the nonmetropolitan counties of Arkansas and Pennsylvania that were involved in shale gas extraction.

\subsection{Implementation of the Synthetic Control Method}

We use the synthetic control method (SCM) to estimate a counterfactual for each of the states. ${ }^{2}$ Rather than necessarily matching to a particular state, in the SCM the counterfactual for each state is a weighted average of the other states based on economic characteristics of the states; in weighting the comparison states, the SCM creates a synthetic control group. The weights are obtained in fitting the pre-treatment trends in educational attainment in the boom state with the synthetic of other non-boom states based on the pre-intervention state characteristics. The difference between the counterfactual and the actual outcomes in the posttreatment period relative to the difference prior to the treatment period is the effect of the fracking boom in the state. We exclude other energy states, including the other fracking boom states, from consideration in the construction of the synthetic control group for each state.

An advantage of the SCM over the difference-in-differences approach is that in SCM the effects of observables are not assumed to be time-invariant. With a sufficiently long preintervention period, the matching on pre-intervention characteristics and outcomes in SCM

\footnotetext{
${ }^{1}$ The nonmetropolitan employment shares for Montana, North Dakota and West Virginia are 0.65, 0.52 and 0.39, respectively. The other states listed by Cascio and Narayan (2015) as possessing clusters of high oil and gas reserves, with the shares presented in parentheses are Louisiana (0.17), Oklahoma (0.36), Pennsylvania (0.12) and Texas (0.13). Source of total state employment, including by metropolitan and nonmetropolitan shares: U.S. Bureau of Economic Analysis, State and Local Personal Income (www.bea.gov, accessed September 20, 2015).

${ }^{2}$ We use the program package Synth in STATA to perform the SCM analysis (http://web.stanford.edu/ jhain/synthpage.html).
} 
implicitly matches on unobservables over time (Abadie et al., 2010). Because technical

presentations of the SCM can be found elsewhere (Abadie and Gardeazabal, 2003; Abadie et al., 2010; Munasib and Rickman, 2015) we only discuss its implementation in our study.

We select the treatment year based on changes in U.S. Bureau of Economic Analysis oil and gas employment in the state. For North Dakota and West Virginia the treatment year is 2006, where for Montana is 2007, though as discussed below changing these by one year does not affect the results. Cascio and Narayan (2015) use a common treatment year of 2006 for all labor markets examined because that is when national production from unconventional (horizontal and directional) wells began to increase dramatically; they confirmed with event analysis that significant fracking did not begin before 2006. Munasib and Rickman (2015) report that changing the treatment one year in either direction did not much change their SCM results because the intensity of fracking increased over the treatment period, producing larger effects later in the period.

Placebo analysis is performed for each state in statistical inference about the educational attainment estimates. For each fracking boom state, each state in the donor pool is assumed to be exposed to the fracking boom treatment, where the remaining states, including the fracking boom state, form the donor pool. With the absence of fracking booms in the donor states, all else equal, a reduction in educational attainment in the placebo state relative to its synthetic control is not expected. The ranking of the fracking boom treatment effect relative to the donor states serves the purpose of statistical inference. Abadie et al. (2010) consider the treatment effect to be significant if it is ranked first relative to the estimated placebo effects for the donor states. 


\subsection{Outcome Variables}

The educational attainment data are for persons ages 18-24 from the pooled 2006-2013 one-percent American Community Surveys (ACS) obtained from IPUMS (Ruggles et al., 2015). We examine effects on high school attainment and college attainment. High school attainment is defined as having either a high school or GED diploma, and our measure of high school completion includes those who have attended at least some college. College attainment is defined as having attended college, though not necessarily graduating. We examine educational attainment effects for both males and females in the age cohort to increase sample size and because of potential general equilibrium effects on other sectors in the economy (Munasib and Rickman, 2015).

We associate educational attainment of an individual to the state in which they were born and the year they turn age 18 , which is computed as the survey year minus age at the time of the survey plus 18 . Thus, an individual is assumed treated by the fracking boom if he/she turned age 18 during the treatment year or later. Persons turning 18 before the treatment year are considered to never have been treated. Thus, we are able to estimate educational attainment from year 2000 to year 2013 for each state. We do not use data from the 2000-2005 ACS because these exclude persons living in group quarters, which include college dormitories. Excluding college students living in dorms substantially alters the composition of the sample and makes the 2000-2005 ACS unusable for our analysis.

Cohorts can differ in the number of times they are observed in the analytical sample.

Some cohorts are observed only once, while others are observed up to seven times, i.e., once at each age between 18 and 24. For example, persons age 18 in year 2000 are observed in our analytic sample until age 24 in 2006; in 2007-2013 they are ages 25 and older and have aged out 
of our analytical sample. Similarly, persons of age 18 in 2013 are only observed once because they were too young for sample inclusion before the 2013 ACS. The number of times cohorts are observed increases around the initial treatment years, which is shown in the Appendix Table. We also only include those born in the state, which by construction omits in-migration effects on educational attainment outcomes. ${ }^{3}$

The educational attainment variables used in the SCM analysis are calculated as regression-adjusted mean education levels by state of birth and year age 18. Specifically, we estimate linear probability models separately in regressing the two individual-level education outcomes on a set of dummy variables for age, sex, and race/ethnicity. ${ }^{4} \mathrm{We}$ then compute mean residuals by state of birth and year age 18 . Using mean regression residuals instead of variable means controls for changes in educational attainment related to demographic shifts. This is especially helpful in our case because cohorts are observed multiple times and at different ages. The mean residuals can be interpreted as differences across cohorts and states in educational attainment levels. The high school attainment mean residual reflects differences in high school completion rates, and the college attainment mean residual reflects differences in rates attending at least some college. The earliest treated cohorts are still relatively young in 2013, so we are unable to effectively examine very long-term degree completion until more data become available.

\footnotetext{
${ }^{3}$ To some extent this will create measurement error in the treatment because many people will leave their native state before high school age. Thus, treatment effect estimates will be attenuated toward zero, and therefore understate the true magnitudes of the effects. In the 2006-2013 ACS, 75.7 percent of persons age 18 reside in their native state.

${ }^{4}$ These results are available from the authors by request. The raw means in our sample for the individual-level high school and college attainment variables are 0.852 and 0.542 , respectively, meaning that more than 85 percent have at least a high school diploma (or GED) and more than 54 percent have attended at least some college.
} 


\subsection{Predictor Variables}

A variety of demographic and economic variables are used as predictor variables in the construction of the synthetic controls. From the Economic Research Service (ERS) of the U.S. Department of Agriculture (USDA, 2015) we include variables reflecting industry composition of the counties. We account for whether the state was heavily dependent on farming, manufacturing, or mining. Because industry dependence is based on the shares of earnings during the period of 1998 to 2000, it is pre-determined to the treatment period. County-level estimates provided by ERS are aggregated to the state level using beginning-period county employment shares. The effects of industry composition also are captured by an industry mix employment growth measure over the period 2000 to 2007 . The industry mix measure is from the well-known shift-share model in regional science and represents the growth expected over the period in the state based on its initial composition of fast- and slow-growing industries nationally (Loveridge and Selting, 1998). The measure was calculated at the county level using four-digit NAICs data by Dorfman et al. (2011) and aggregated to the state level. ${ }^{5}$ The industry mix measure can be used to capture exogenous employment shifts because beginning-period area employment shares and national industry growth rates are used in the calculation (Bartik, 1991).

Other ERS variables include (USDA, 2015): the natural amenity attractiveness of the state (McGranahan, 1999), obtained as a population-weighted aggregate of county natural amenity scale values; the composition of counties that are a retirement destination, designated as such if the number of residents over 60 years of age increased by more than 15 percent between 1990 and 2000; the state composition of nonmetropolitan counties that were recreation dependent based on several indicators measured by year 2000; the state composition of industries

\footnotetext{
${ }^{5}$ We are grateful to the authors of Dorfman et al. (2011) for use of these county data to construct the state aggregates.
} 
that lost population during 1980-1990 and 1990 and 2000; and the state composition of counties that had a poverty rate of 20 percent or higher in each of the 1970, 1980, 1990 and 2000 censuses. We also include measures of urbanization: the state composition of rural-urban continuum code values from ERS, which are based on population and size of the metropolitan area/contiguity to a metropolitan area (USDA, 2015); state population density in year 2000 to capture agglomeration economies; and per capita income in year 2000 to capture convergence effects and agglomeration economies.

We also include variables reflecting the educational attainment shares of the adult population 25 years and older from the 2000 Census of Housing and Population: at least a bachelor's degree, only an associates college degree, and only a high school degree. To account for public policy differences, we also include Fraser Institute's Economic Freedom Index for the beginning of the decade (Goetz et al., 2011), which reflect regulatory, property rights and tax policy that influence the business climate. Finally, following Abadie et al. (2010), the first, mid, and last years of the pre-treatment period are included as predictor variables.

\section{Results}

Figures 1-3 and Tables 1-3 display the results of estimating the effects of the shale oil and gas boom on high school and college attainment for Montana, North Dakota and West Virginia. The figures show pre- and post-treatment educational attainment mean residuals by year for both the treated state and the synthetic control. Each table displays the weights that states received in the construction of the synthetic control unit. Also displayed is the estimated treatment effect, the difference-in-differences (DID). DID is calculated as the difference in the mean differences, between educational attainment in the shale oil and gas boom state and that of the synthetic control, in the pre-treatment period (DP) from that in the post-treatment period (DT). The DID ranking for the state compared to those in the placebo analysis is displayed in the line below the 
DID; the state with the most negative treatment effect on educational attainment receives a rank of 1 , while the state with the least negative/most positive treatment effect receives the lowest rank of 39.

\subsection{Educational Attainment in Montana}

Figure 1 displays the pre- and post-treatment patterns in high school attainment (top graph) and college attainment (bottom graph) for Montana and its synthetic control units. Both graphs show fairly narrow differences between Montana and its synthetic control prior to the treatment year of 2007, widening afterwards, particularly by 2013. Educational attainment generally drops in Montana, while it rises in the synthetic control units, particularly for high school attainment.

Panel A of Table 1 shows that for high school attainment, three states, with fairly equal weights, comprise the synthetic control unit: Nebraska, South Carolina and South Dakota. For college attainment the contributors to the synthetic control, in order of importance are Idaho, South Dakota and Arkansas. Panel B shows that there was a nearly six percentage point reduction in high school attainment in Montana relative to its synthetic control, with a comparable figure for college attainment of approximately four percentage points. ${ }^{6}$ The magnitudes are relatively large and suggest economically meaningful effects. The DID was more negative for Montana than for any of the placebo states for both high school and college attainment, indicating statistical significance.

\subsection{Educational Attainment in North Dakota}

Figure 2 displays the pre- and post-treatment patterns in high school attainment (top graph) and college attainment (bottom graph) for North Dakota and its synthetic control units.

\footnotetext{
${ }^{6}$ Our DID estimates are computed as averages over the entire post-treatment time period. However, the strength of the treatment from the energy booms grows over time and the estimated treatment effects also generally increase over time.
} 
Educational attainment in North Dakota closely follows that in the synthetic control units prior to the treatment year of 2006. Subsequent to the treatment year, educational attainment drops in North Dakota and rises in the synthetic control units. College attainment initially drops the quickest in North Dakota, where high school attainment drops most precipitously at the end of the treatment period.

From Panel A of Table 2, we see the largest weight in the synthetic control unit for high school attainment is given to New Jersey, with Nebraska the only other state receiving significant weight. Although the choice of New Jersey may appear surprising, New Jersey and North Dakota have similar values for the educational attainment predictor variables (measured in year 2000) and for the outcome variables during the pre-treatment period. For college attainment, Nebraska receives almost the entire weight. ${ }^{7}$ Nebraska received the second largest weight in the synthetic control for non-metropolitan North Dakota in the study of shale oil and gas employment impacts of Munasib and Rickman (2015), where only three states received significant weight (the other two states were South Dakota and Iowa). Panel B shows approximately a 5.6 percentage point relative reduction in high school attainment in North Dakota, with a corresponding estimate for college attainment of 5.3 percentage points. Placebo analysis reveals that the reductions in educational attainment in North Dakota were larger than in any of the donor pool states, indicating statistical significance.

\subsection{Educational Attainment in West Virginia}

Figure 3 displays the pre- and post-treatment patterns in high school attainment (top graph) and college attainment (bottom graph) for West Virginia and its synthetic control units.

\footnotetext{
${ }^{7}$ Using the Nebraska and New York state weights produced by the college attainment SCM for North Dakota in place of the New Jersey and Nebraska weights in constructing the synthetic control produces a slightly larger relative reduction in North Dakota high school attainment. Thus, the high school attainment result is not an artifact of using New Jersey. In fact, difference-in-difference analysis using all states for comparison to North Dakota produces comparable estimated treatment effects for North Dakota (see section 3.5).
} 
Educational attainment in West Virginia fairly closely follows that of its synthetic control units prior to the treatment year, particularly for high school attainment. Both high school and college attainment fall after the treatment year of 2006, but both rebound later in the treatment period. High school attainment of the synthetic control unit initially increases in the post- treatment period but then falls. College attainment of the synthetic control unit mostly continually rises throughout the treatment period. A complicating factor in West Virginia is coal mining, in which employment increased the most prior to the treatment year, slightly increased afterwards, flattened out from 2011-2012 and then declined in 2013. Oil and gas employment, and employment in mining support activities, increased dramatically during the treatment period. The declines in coal mining may in part contribute to the rebound in educational attainment at the end of the treatment period. Also, the sample for 2013 from which educational attainment is calculated is smaller. It only includes those surveyed at age 18 in 2013; whereas, for 2012 the sample includes those surveyed at age 18 in 2012 and those surveyed at age 19 in 2013.

Panel A of Table 3 shows that several states contributed to the synthetic control unit for high school attainment. Kentucky, with over three-fifths of the weight was the largest contributor. Pennsylvania had a weight over one-fifth; whereas South Dakota had a weight over one-tenth. Although Pennsylvania possesses shale gas resources, potentially biasing the treatment effect downwards, previous studies of Pennsylvania failed to find significant shale gas-related employment effects (Weinstein and Partridge, 2011; Munasib and Rickman, 2015). Only Kentucky and Maine contributed to the synthetic control for college attainment. From Panel B it can be seen that there was a 2.6 percentage point relative reduction in high school attainment in West Virginia, in which one placebo state had a larger estimated relative reduction. For college 
attainment, the estimated effect was a 5.5 percentage point reduction, which was higher than that of any state in the donor pool.

\subsection{Differential Effects by Gender}

In addition to finding negative effects of the shale oil and gas boom on male high school dropout rates, Cascio and Narayan (2015) find a significantly negative effect for males relative to females. This confirms the authors' expectations because the shale and oil and gas workforce is primarily male. Yet, because of spillover (general equilibrium) effects in other sectors, it could be expected that employment of lower-skilled females also increases, potentially reducing their educational attainment. For example, Munasib and Rickman (2015) report that over two additional jobs are stimulated in non-oil and gas sectors for every additional oil and gas job created in North Dakota during its oil and gas boom. There also can be complex effects on household decisions resulting from increased employment of males.

Therefore, we rerun the synthetic control analysis for every state using the educational attainment outcomes of males relative to females. In results not shown, we fail to find a consistent treatment effect on the gender gap in educational outcomes. Montana and North Dakota had negative relative male high school attainment treatment effects of 2.5 and 1.2 percentage points, respectively, while West Virginia had a positive relative effect of 3.6 percentage points. Thus, we find slight support for the high school findings of Cascio and Narayan (2015) in two of our three cases. There was not any differential effect on college attainment by gender in West Virginia and positive relative effects in the other two states. We caution, however, that the samples for our educational attainment outcomes by gender may be too small to precisely estimate gender differences, particularly for the ends of the treatment periods. 


\subsection{Sensitivity Analysis}

Although Munasib and Rickman (2015) found the synthetic control method to produce robust results for economic changes in shale boom areas, we perform some sensitivity analysis (not shown). First, we experiment with changing the start of the treatment period for each state. Secondly, we use a subset of our predictor variables. Thirdly, we remove contiguous states that were part of the synthetic control for each state from the potential donor pool. Finally, we perform traditional difference-in-differences estimation for each treatment state, using all 38 SCM donor pool states as the comparison group.

Using 2006 as the first treatment year for Montana instead of 2007 causes the estimated DID treatment effects to become 7.2 and 5.3 percentage points for high school and college attainment. Despite the more negative estimated treatment effects, we maintain 2007 as the first treatment year for Montana because the charts from using 2006 have the same patterns as those shown in Figure 1 for 2007, which show a clearer treatment effect beginning in 2007. South Dakota drops out from contributing to the synthetic control for high school attainment, with Nebraska now receiving over twice the weight of the only other contributing state, South Carolina. Idaho drops out of the synthetic control for college attainment, with Utah and Arkansas now contributing to the synthetic control, where Utah has approximately twice the weight of the two other states.

The estimated DID treatment effects for North Dakota also become more negative for high school and college attainment at 6.3 and 6.4 percentage points when 2007 replaces 2006 as the first treatment year. The charts continue to suggest 2006 as the first treatment year though. Both Nebraska and New Jersey remain as the two contributors to the synthetic control for high school attainment with approximately the same weights. But for college attainment New Jersey 
replaces New York as a contributing state, though Nebraska remains the state with the far largest weight-approximately 2.5 times the weight for New Jersey.

Replacing 2006 with 2007 as the first treatment year for West Virginia also produces slightly more negative estimated DID treatment effects; the estimated relative reduction in high school attainment is now 3.3 percentage points and the estimated effect for college attainment is 5.8 percentage points. Nevertheless, the charts continue to suggest 2006 as the first treatment year. Five states now comprise the synthetic control of high school attainment for West Virginia, which in order of importance are Kentucky, South Dakota, Pennsylvania, Arkansas and Maine. Kentucky and Maine remain as the two contributors to the synthetic control of college attainment, with Kentucky's weight slightly increasing.

Secondly, we rerun the SCMs using a limited set of the predictor variables. We remove the economic freedom index, industry mix employment growth, mining dependence, population density, persistent poverty status, and recreation status of state nonmetropolitan counties. This reduces redundancy in the predictor variables, leaving in the variables representing the most fundamental aspects of state economies. The DID estimates for high school attainment and college attainment based on the limited set of predictor variables are nearly the same across all three states, never changing more than a couple of tenths percentage points: both are slightly more negative for Montana; it is the same for high school attainment and barely less negative for college attainment in North Dakota; and it is slightly less negative for high school attainment and slightly more negative for college attainment in West Virginia. There were only a few cases of changes in the states used in constructing the synthetic controls: for college attainment in Montana (the number of contributing states increased from three to five) and for both high 
school (increasing from four to six) and college attainment (Tennessee replaced Maine) in West Virginia.

Thirdly, we remove the contiguous states that contributed to the synthetic controls in the base cases. Contiguous states could experience a treatment effect if their residents commuted or migrated to the state where the oil and gas shale and boom jobs were created (Wrenn et al., 2015) or if there were economic spillovers across state borders. This would cause the estimated treatment effects to be biased towards zero.

For Montana, removing Idaho and South Dakota from the donor pool caused the reduction to high school attainment to become more negative at 7.2 percentage points, while the estimate for college attainment was within one-tenth of a percentage point of the base estimate. For high school attainment, the contributors to the synthetic control, in order of importance, are Nebraska, South Carolina and Mississippi. The contributors for college attainment in order of importance are Utah, Kentucky and Vermont. In each case the largest weight exceeded 0.6. There were not any contiguous states used in the construction of the synthetic control units for North Dakota in the base case. For West Virginia, removing Kentucky and Pennsylvania caused the estimated reductions to become more negative at 3.3 and 6.7 percentage points, respectively, for high school and college attainment. The contributors for the high school synthetic control in West Virginia in order of importance are Arkansas, Utah and Maine, while for college attainment they are Arkansas, Maine and Delaware. The weights for Arkansas are 0.435 for high school attainment and 0.746 percent for college attainment. The generally more negative effects confirm that the base case estimates may be slightly understated for Montana and West Virginia.

As a final sensitivity check, we estimated traditional difference-in-differences coefficients separately for Montana, North Dakota, and West Virginia defining the control group 
to include all 38 donor pool states, equally weighted. This more naïve approach does not account for pre-treatment trends and may create worse matches compared to SCM. Nevertheless, it produces fairly comparable treatment effects estimates. The estimated percentage point reduction for high school and college attainment in each treatment state are as follows (with high school attainment effects listed first in parentheses): Montana $(6.8,5.7)$, North Dakota $(5.1,7.5)$ and West Virginia $(2.7,3.7)$. We believe that the Synthetic Control Method produces the most accurate estimates of the treatment effects, but the traditional DID results support the robustness of our results to alternative constructions of synthetic control units.

\section{Summary and Discussion}

Using novel methods for measuring educational attainment and constructing counterfactuals this study examines the link between shale oil and gas development and educational attainment. Montana, North Dakota, and West Virginia, three economically-small, more rural states, with clusters of high levels of shale oil or gas, are examined. The Synthetic Control Method (SCM) is used to establish the counterfactuals for educational attainment in nonboom states. Energy states more broadly are excluded from consideration in construction of the counterfactuals.

We find reductions in both high school and college attainment in all three states relative to their counterfactuals, which are robust to considerations of alternative treatment years, predictor variables and omission of contiguous states in the construction of the counterfactuals. Our results stand in contrast to the findings of Weber (2014). Weber (2014) only examined shale gas counties in the south central part of the nation. Munasib and Rickman (2015) found much larger employment multiplier effects in the oil counties of North Dakota relative to the gas counties in Arkansas and Pennsylvania. This makes adverse effects on educational attainment more likely in the shale oil resource states we examined. Also, Weber (2014) examined both 
high school and college attainment of the entire population in the shale gas counties, which included that of in-migrants. Our focus on educational attainment of the native born population removes in-migration effects on educational attainment.

Our results are more consistent with those of Cascio and Narayan (2015). But in contrast to Cascio and Narayan (2015), we examine the effects on college education in addition to those on high school education. We also examine high school attainment rather than high school dropouts, which allows for better inference of medium-term human capital effects of shale oil and gas development (Emery et al., 2012). Also somewhat consistent with Cascio and Narayan (2015), we find slightly greater reduction in high school attainment for males in Montana and North Dakota, though not for West Virginia

If the current bust in shale and oil gas development continues for a significant period of time, future research will be better able to address the long-term effects of booms and busts in shale oil and gas development on human capital formation. Challenging issues of separating educational attainment of migrants from natives remain. We did not separately address the effects of shale and oil gas development on out-migrants, or whether the out-migrants possessed differential levels of educational attainment. The impacts of shale oil and gas development on long-term educational attainment remains a key issue in the debate regarding the overall effects of shale oil and gas development on states and localities. 


\section{References}

Abadie, Alberto, Alexis Diamond and Jens Hainmueller, 2010. "Synthetic Control Methods for Comparative Case Studies: Estimating the Effect of California's Tobacco Control Program," Journal of the American Statistical Association 105, 493-505.

Abadie, Alberto and Javier Gardeazabal, 2003. "The Economic Costs of Conflict: A Casecontrol Study for the Basque Country," American Economic Review 93 (1),113-132.

Bartik, Timothy J., 1991. Who Benefits from State and Local Economic Development Policies? Upjohn Institute, Kalamazoo, MI.

Black, Dan A., Terra G. McKinnish, and Seth G. Sanders, 2005. "Tight Labor Markets and the Demand for Education: Evidence from the Coal Boom and Bust," Industrial and Labor Relations Review 59(1), 3-16.

Brown, Jason P., 2014. "Production of Natural Gas from Shale in Local Economies: A Resource Curse or Blessing?" Federal Reserve Bank of Kansas City Economic Review 99 (1), 5-33.

Cascio, Elizabeth U. and Ayushi Narayan, 2015. "Who Needs a Fracking Education? The Educational Response to Low-Skill Biased Technological Change," NBER Working Paper 21359.

Dorfman, Jeffrey, Partridge, Mark D., Galloway, Hamilton, 2011. “Are High-tech Employment and Natural Amenities Linked? Answers from a Smoothed Bayesian Spatial Model," Spatial Economic Analysis 6, 397-422.

Emery, J.C. Herbert, Ana Ferrer and David Green, 2012. "Long-term Consequences of Natural Resource Booms for Human Capital Accumulation,” ILR Review 65(3), 708-734.

Goetz, Stephan, Mark Partridge, Dan Rickman, Shibalee Majumdar, 2011. "Sharing the Gains of Local Economic Growth: Race to the Top vs. Race to the Bottom Economic Development Policies", Environment and Planning C, 29 (3), 428-456.

Haggerty, Julia, Patricia H. Gude, Mark Delorey and Ray Rasker, 2014. "Long-term Effects of Income Specialization in Oil and Gas Extraction: The U.S. West, 1980-2011," Energy Economics 45, 186-195.

Loveridge, Scott and Anne C. Selting, 1998. "A Review and Comparison of Shift-Share Identities," International Regional Science Review 21(1), 37-58.

McGranahan, David A., 1999. Natural Amenities Drive Rural Population Change. AER 781. Washington D.C.: Economic Research Service, U.S. Department of Agriculture.

Michaels, Guy, 2011. "The Long-Term Consequences of Resource-Based Specialization," The Economic Journal 121(551), 31-57. 
Morrissette, René, Ping Ching Winnie Chan and Yuqian Lu, 2015. "Wages, Youth Employment, and School Enrollment Recent Evidence from Increases in World Oil Prices," The Journal of Human Resources 50(1), 222-253.

Munasib, Abdul and Dan S. Rickman, 2015. "Regional Economic Impacts of the Shale Gas and Tight Oil Boom: A Synthetic Control Analysis," Regional Science and Urban Economics 50, 117.

Papyrakis, Elissaios and Reyer Gerlagh, 2007. "Resource Abundance and Economic Growth in the United States," European Economic Review 51(4), 1011-1039.

Ruggles, Steven, Katie Genadek, Ronald Goeken, Josiah Grover, and Matthew Sobek. Integrated Public Use Microdata Series: Version 6.0 [Machine-readable database]. Minneapolis: University of Minnesota, 2015.

U.S. Department of Agriculture, Economic Research Service, 2015. Data last September 22, 2015 at http://www.ers.usda.gov/data-products/county-typology-codes/descriptions-andmaps.aspx\#poploss

U.S. Energy Information Administration, 2015. Annual Energy Outlook 2015 with Projections to 2040. DOE/EIA-0383.

Walker, Anne, 2013. "An Empirical Analysis of Resource Curse and the Educational Attainment Channel in the Appalachian Region," Dissertation for the College of Business and Economics at West Virginia University.

Weber, Jeremy G., 2012. "The Effects of a Natural Gas Boom on Employment and Income in Colorado, Texas, and Wyoming," Energy Economics 34 (5), 1580-1588.

Weber, Jeremy G., 2014. "A Decade of Natural Gas Development: The Making of a Resource Curse?" Resource and Energy Economics 37, 168-183.

Weinstein, Amanda, 2014. "Local Labor Market Restructuring in the Shale Boom," Journal of Regional Analysis \& Policy 44 (1), 71-92.

Weinstein, Amanda L., Partridge, Mark D., 2011. The Economic Value of Shale Natural Gas in Ohio. The Swank Program in Rural-Urban Policy Summary and Report.

Wrenn, Douglas H., Timothy W. Kelsey, and Edward C. Jaenicke, 2015. "Resident versus Nonresident Employment Associated with Marcellus Shale Development,"Agricultural and Resource Economics Review 44(2), 1-19. 

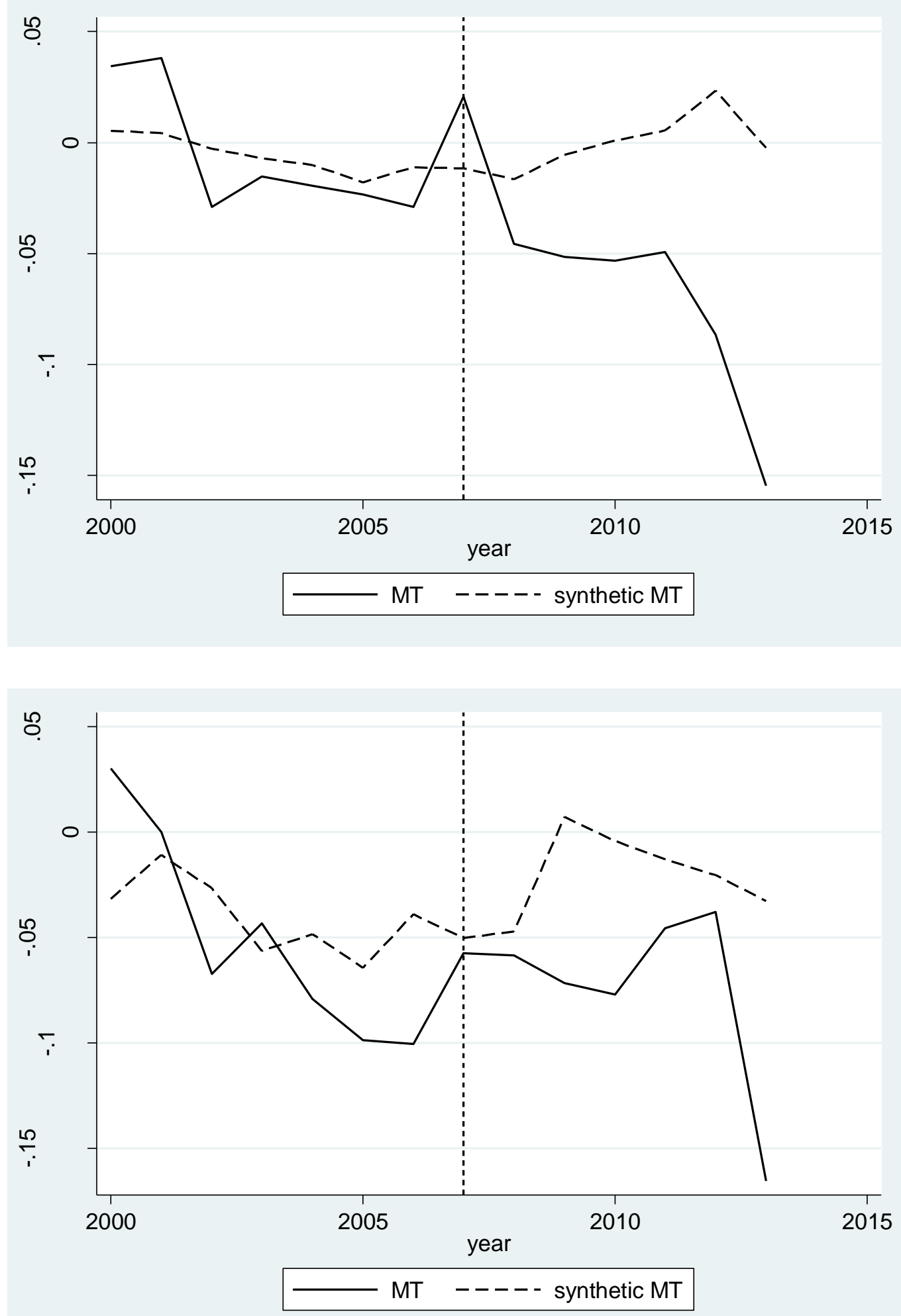

Figure 1: Treatment versus Synthetic Control Unit Educational Attainment: Montana 
Table 1: SCM Estimation of the Impact of Shale Gas and Tight Oil Boom on Educational Attainment in Montana

\begin{tabular}{|l|r|r|}
\hline \multicolumn{3}{|c|}{ Panel A: W-weights } \\
\hline State & High School & rollege \\
\hline Alabama & 0 & 0 \\
\hline Arizona & 0 & 0 \\
\hline Arkansas & 0 & 0.111 \\
\hline California & 0 & 0 \\
\hline Connecticut & 0 & 0 \\
\hline Delaware & 0 & 0 \\
\hline Florida & 0 & 0 \\
\hline Georgia & 0 & 0 \\
\hline Idaho & 0 & 0.456 \\
\hline Illinois & 0 & 0 \\
\hline Indiana & 0 & 0 \\
\hline Iowa & 0 & 0 \\
\hline Kansas & 0 & 0 \\
\hline Kentucky & 0 & 0 \\
\hline Maine & 0 & 0 \\
\hline Maryland & 0 & 0 \\
\hline Massachusetts & 0 & 0 \\
\hline Michigan & 0 & 0 \\
\hline Minnesota & 0 & 0 \\
\hline Mississippi & 0 & 0 \\
\hline Missouri & 0 & 0 \\
\hline Nebraska & 0 & 0 \\
\hline New Hampshire & 0 & 0 \\
\hline New Jersey & 0 & 0 \\
\hline New York & 0 & 0 \\
\hline North Carolina & 0 & 0 \\
\hline Ohio & 0 & 0 \\
\hline Oregon & 0 & 0 \\
\hline Pennsylvania & 0 & 0 \\
\hline Rhode Island & 0 & 0 \\
\hline South Carolina & 0 & 0 \\
\hline South Dakota & 0 & 0 \\
\hline Tennessee & 0 & 0 \\
\hline Utah & 0 & 0 \\
\hline Vermont & 0 & 0 \\
\hline Virginia & 0 & 0 \\
\hline Washington & 0 & 0 \\
\hline Wisconsin & 0 & 0 \\
\hline & 0 & 0 \\
\hline DID (DT)-(DP) & 0 & 0 \\
\hline Treatment Rank & 0 & 0 \\
\hline
\end{tabular}



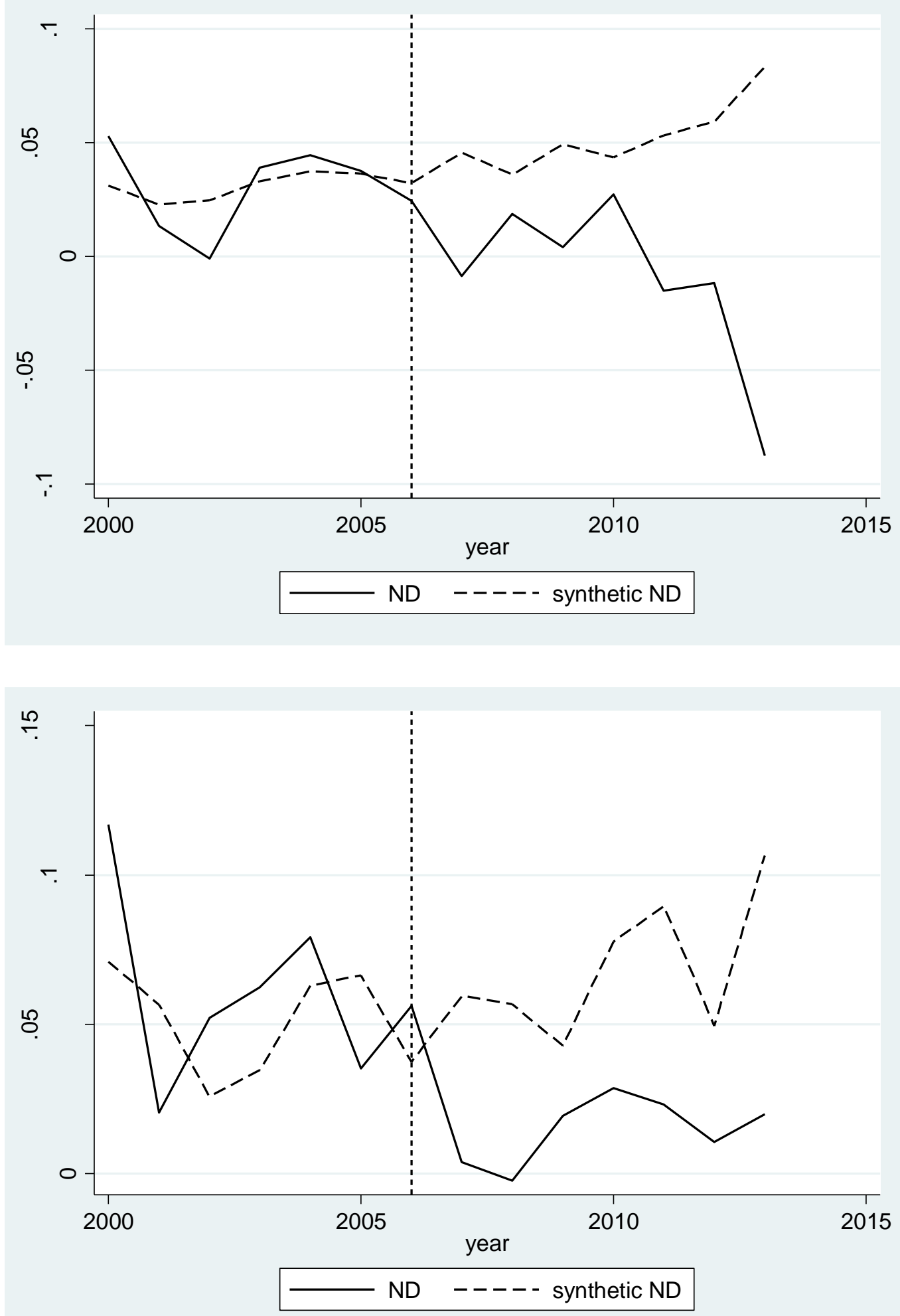

Figure 2: Treatment versus Synthetic Control Unit Educational Attainment: North Dakota 
Table 2: SCM Estimation of the Impact of Shale Gas and Tight Oil Boom on Educational Attainment in North Dakota

\begin{tabular}{|l|r|r|}
\hline \multicolumn{3}{|c|}{ Panel A: W-weights } \\
\hline State & High School & rollege \\
\hline Alabama & 0 & 0 \\
\hline Arizona & 0 & 0 \\
\hline Arkansas & 0 & 0 \\
\hline California & 0 & 0 \\
\hline Connecticut & 0 & 0 \\
\hline Delaware & 0 & 0 \\
\hline Florida & 0 & 0 \\
\hline Georgia & 0 & 0 \\
\hline Idaho & 0 & 0 \\
\hline Illinois & 0 & 0 \\
\hline Indiana & 0 & 0 \\
\hline Iowa & 0 & 0 \\
\hline Kansas & 0 & 0 \\
\hline Kentucky & 0 & 0 \\
\hline Maine & 0 & 0 \\
\hline Maryland & 0 & 0 \\
\hline Massachusetts & 0 & 0 \\
\hline Michigan & 0 & 0 \\
\hline Minnesota & 0 & 0 \\
\hline Mississippi & 0 & 0 \\
\hline Missouri & 0 & 0 \\
\hline Nebraska & 0 & 0 \\
\hline New Hampshire & 0 & 0 \\
\hline New Jersey & 0 & 0 \\
\hline New York & 0 & 0 \\
\hline North Carolina & 0 & 0 \\
\hline Ohio & 0 & 0 \\
\hline Oregon & 0 & 0 \\
\hline Pennsylvania & 0 & 0 \\
\hline Rhode Island & 0 & 0 \\
\hline South Carolina & 0 & 0 \\
\hline South Dakota & 0 & 0 \\
\hline Tennessee & 0 & 0 \\
\hline Utah & 0 & 0 \\
\hline Vermont & 0 & 0 \\
\hline Virginia & 0 & 0 \\
\hline Washington & 0 & 0 \\
\hline Wisconsin & 0 & 0 \\
\hline & 0 & 0 \\
\hline DID (DT)-(DP) & 0 & 0 \\
\hline Treatment Rank & 0 & 0 \\
\hline & 0 & 0 \\
\hline
\end{tabular}



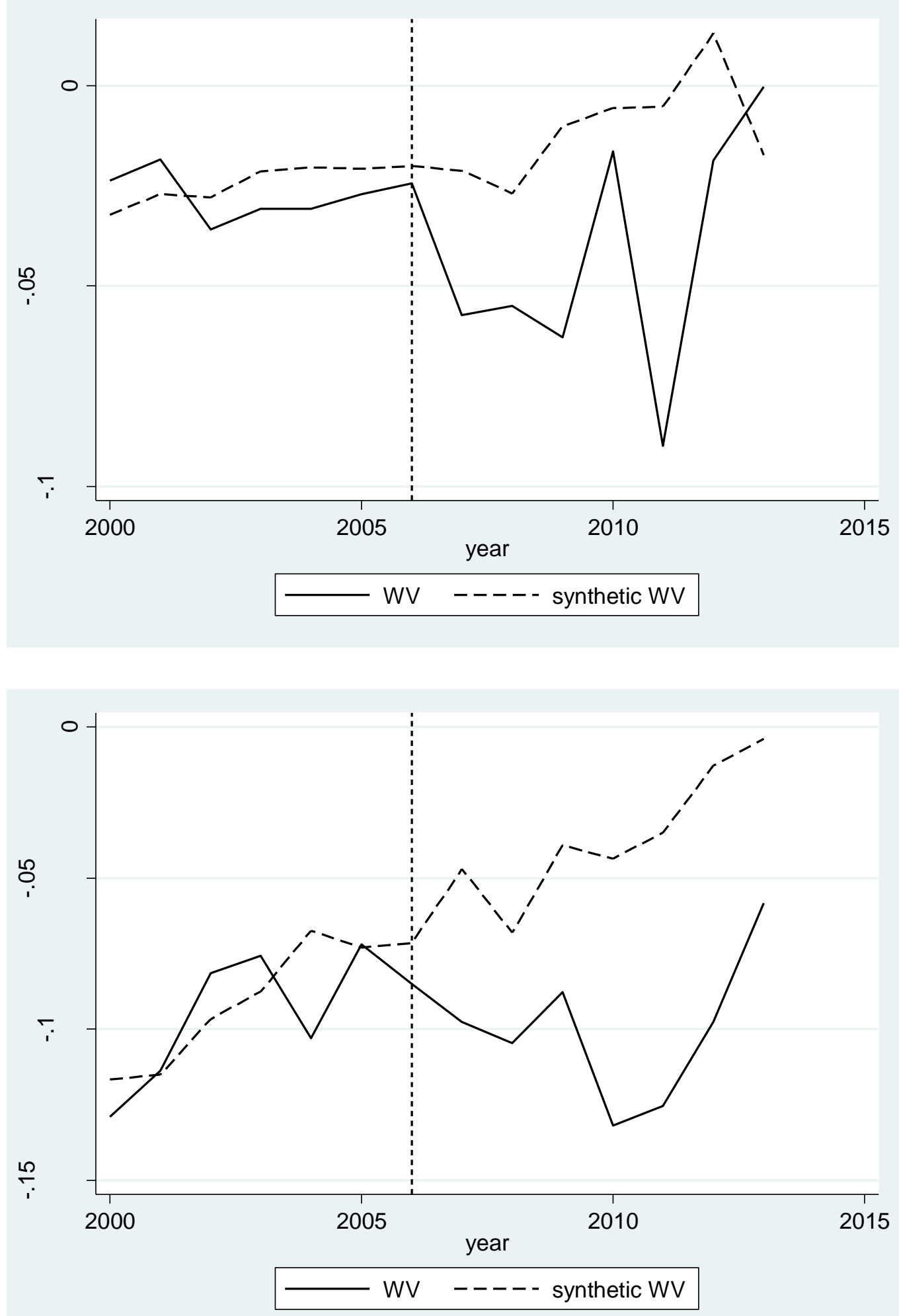

Figure 3: Treatment versus Synthetic Control Unit Educational Attainment: West Virginia 
Table 3: SCM Estimation of the Impact of Shale Gas and Tight Oil Boom on Educational Attainment in West Virginia

\begin{tabular}{|l|r|r|}
\hline \multicolumn{3}{|c|}{ Panel A: W-weights } \\
\hline State & High School & College \\
\hline Alabama & 0 & 0 \\
\hline Arizona & 0 & 0 \\
\hline Arkansas & 0 & 0 \\
\hline California & 0 & 0 \\
\hline Connecticut & 0 & 0 \\
\hline Delaware & 0 & 0 \\
\hline Florida & 0 & 0 \\
\hline Georgia & 0 & 0 \\
\hline Idaho & 0 & 0 \\
\hline Illinois & 0 & 0 \\
\hline Indiana & 0 & 0 \\
\hline Iowa & 0 & 0 \\
\hline Kansas & 0 & 0 \\
\hline Kentucky & 0.62 & 0.854 \\
\hline Maine & 0 & 0.146 \\
\hline Maryland & 0 & 0 \\
\hline Massachusetts & 0 & 0 \\
\hline Michigan & 0 & 0 \\
\hline Minnesota & 0 & 0 \\
\hline Mississippi & 0 & 0 \\
\hline Missouri & 0 & 0 \\
\hline Nebraska & 0 & 0 \\
\hline New Hampshire & 0 & 0 \\
\hline New Jersey & 0 & 0 \\
\hline New York & 0 & 0 \\
\hline North Carolina & 0 & 0 \\
\hline Ohio & 0 & 0 \\
\hline Oregon & 0 & 0 \\
\hline Pennsylvania & 0 & 0 \\
\hline Rhode Island & 0 & 0 \\
\hline South Carolina & 0 & 0 \\
\hline South Dakota & 0 & 0 \\
\hline Tennessee & 0 & 0 \\
\hline Utah & 0 & 0 \\
\hline Vermont & 0 & 0 \\
\hline Virginia & 0 & 0 \\
\hline Washington & 0 & 0 \\
\hline Wisconsin & 0 & 0 \\
\hline & 0 & 0 \\
\hline DID (DT)-(DP) & 0 & 0 \\
\hline Treatment Rank & 0 & 0 \\
\hline
\end{tabular}


Appendix Table: ACS Age Cohorts (Sample Cohorts Highlighted in Yellow)

\begin{tabular}{|c|c|c|c|c|c|c|c|c|c|c|}
\hline $\begin{array}{c}\text { Year } \\
\text { Age } 18\end{array}$ & $\begin{array}{l}\text { Number } \\
\text { of Times } \\
\text { Cohort Is } \\
\text { Observed }\end{array}$ & $\begin{array}{l}\text { ACS Year(s) } \\
\text { Cohort Is } \\
\text { Observed }\end{array}$ & $\begin{array}{l}\text { Age in } \\
2006 \\
\text { ACS }\end{array}$ & $\begin{array}{l}\text { Age in } \\
2007 \\
\text { ACS }\end{array}$ & $\begin{array}{l}\text { Age in } \\
2008 \\
\text { ACS }\end{array}$ & $\begin{array}{l}\text { Age in } \\
2009 \\
\text { ACS }\end{array}$ & $\begin{array}{l}\text { Age in } \\
2010 \\
\text { ACS }\end{array}$ & $\begin{array}{l}\text { Age in } \\
2011 \\
\text { ACS }\end{array}$ & $\begin{array}{l}\text { Age in } \\
2012 \\
\text { ACS }\end{array}$ & $\begin{array}{l}\text { Age in } \\
2013 \\
\text { ACS }\end{array}$ \\
\hline 2000 & 1 & 2006 & 24 & 25 & 26 & 27 & 28 & 29 & 30 & 31 \\
\hline 2001 & 2 & 2006-2007 & 23 & 24 & 25 & 26 & 27 & 28 & 29 & 30 \\
\hline 2002 & 3 & 2006-2008 & 22 & 23 & 24 & 25 & 26 & 27 & 28 & 29 \\
\hline 2003 & 4 & 2006-2009 & 21 & 22 & 23 & 24 & 25 & 26 & 27 & 28 \\
\hline 2004 & 5 & 2006-2010 & 20 & 21 & 22 & 23 & 24 & 25 & 26 & 27 \\
\hline 2005 & 6 & 2006-2011 & 19 & 20 & 21 & 22 & 23 & 24 & 25 & 26 \\
\hline 2006 & 7 & 2006-2012 & 18 & 19 & 20 & 21 & 22 & 23 & 24 & 25 \\
\hline 2007 & 7 & $2007-2013$ & 17 & 18 & 19 & 20 & 21 & 22 & 23 & 24 \\
\hline 2008 & 6 & $2008-2013$ & 16 & 17 & 18 & 19 & 20 & 21 & 22 & 23 \\
\hline 2009 & 5 & 2009-2013 & 15 & 16 & 17 & 18 & 19 & 20 & 21 & 22 \\
\hline 2010 & 4 & 2010-2013 & 14 & 15 & 16 & 17 & 18 & 19 & 20 & 21 \\
\hline 2011 & 3 & $2011-2013$ & 13 & 14 & 15 & 16 & 17 & 18 & 19 & 20 \\
\hline 2012 & 2 & $2012-2013$ & 12 & 13 & 14 & 15 & 16 & 17 & 18 & 19 \\
\hline 2013 & 1 & 2013 & 11 & 12 & 13 & 14 & 15 & 16 & 17 & 18 \\
\hline
\end{tabular}

